\title{
16. Yüzyıl Osmanlı Dönemini Konu Alan Dönem Filmi Anlatısı için Bir Sembolik Anlam Taşıyıcısı Olan Döneme Özgü İpek Lifli Giysi Dokumalarının Özellikleri
}

INCII YAKUT*

incyakut@hotmail.com

Özet: Çalışmada, 16. yy. Osmanlı dönemi toplum yaşantısını konu alan dönem filmi anlatısında ipek lifli giysi dokumalarının bir simgesel anlatım aracı olarak hangi özellikleri taşıdığı irdelenecektir. Çalışmada, 16. yy. ipek lifli dokumaların döneme özgü öne çıkan sembolik özelliklerinin irdelenmesi, dönem filmleri anlatısının oluşturulması sürecinde ipek lifli dokumaların özellikle karakter tasarımındaki sembolik anlam yaratma düzeyinin anlaşılmasını olanaklı kılacaktır. Çalışmada eleştirel literatür değerlendirmesi ve görsel metin çözümlemesi yapılmıştır. 16. yy. Osmanlı dönemi saray yaşantısında kullanılan ipekli giysi dokumaları padişah ve sarayın ihtişamını vurgulayan sembolik bir özelliğe sahiptir. 16. yy. Osmanlı saray yaşantısını konualan dönem filmleri anlatısında saray yaşantısındaönemli roloynayanöncelikle padişah ve sonra diğer şehzade, hanedan üyeleri, saraydaki üst düzey görevliler gibi saray mensupların temsil eden karakterlerin kostümlerinin tasarımında kullanılacak dokumaların, dönemin sosyal hiyerarşisindeki üst düzeydeki konumlarını sembolize edecek şekilde ipekten ya da ipek görünümüne sahip değerli kumaşlardan yapılmasının sağlanması gerekir. Bunlar, filmdeki karakterlere, mekana ve olaylara yönelik gerçeklik algısının oluşmasında önemli rol oynayacaktır. Ayrıca, giysi aksesuarlarındaki ve karakteri çevreleyen mekandaki dokumalarda ipek lifli kumaşların kullanımı karakter kostümlerinin dokuma özelliklerinin değerini öne çıkaracaktır.

Anahtar kelimeler: Osmanlı dönem filmi, anlatı, sembolik anlam, ipek lifli giysi dokuması, karakter tasarımı, kostüm.

\section{Giriş}

Çalışmada 16. yy. Osmanlı dönemi toplum yaşantısını konu alan dönem filmi anlatısında ipek lifli giysi dokumalarının bir simgesel anlatım aracı olarak hangi özellikleri taşıdığı irdelenecektir. Çalışmada 16. yy. ipek lifli dokumaların döneme özgü öne çıkan sem-bolik özelliklerinin irdelenmesi, dönem filmleri anlatısının oluşturulması sürecinde ipek lifli dokumaların özellikle karakter tasarımındaki sembolik anlam yaratma düzeyinin anlaşılmasını olanaklı kılacaktır. Bu durum çalışmanın önemini ortaya koymaktadir.

\footnotetext{
* Doç. Dr., Kocaeli Üniversitesi İletişim Fakültesi, Radyo Televizyon ve Sinema Bölümü.
} 
Geçmiş yüzyıllara ait bir dönemde belli bir toplumda geçen olayları, toplumun sembolleşmiş kahramanlarını ve toplumun sosyo-kültürel yaşantı tarzını yansıtan ya da bun-lardan esinlenerek oluşturulan filmler genellikle dönem filmleri olarak isimlendirilmektedir. Dönem filmleri içinde özellikle Orta Çağ ve erken Yeni Çağ toplumlarını ele alan filmler de (medieval film ya da middle age film) Orta Çağ filmleri olarak sınıflandırılmaktadır. Genel olarak dönem filmleri özel olarak da Orta Çağ ve erken Yeni Çağ filmleri görsel göstergelerin sembolik anlam taşıdığı bir evreni kurgulamaktadır. Bu kurgulamada filmdeki görsel göstergelerin ve onlara ait sembolik anlamın karşılığının toplumda aranmasına ve bulunmasına olanak tanınır. Bu nedenle dönem filmlerinde toplumdaki gerçeğe dair izler bulunmaktadır. Söz konusu dönemlere ait film anlatısında sembolik evrenin oluşturulmasında kostüm özel bir öneme sahiptir. Burada kostüm, filmde görsel anlatım sağlayan görsel gösterge olduğundan sembollerin yoğun olarak bu görsel gösterge üzerinden oluşturulmasına çalışılır. Dönem filmlerinde kostümün sembolik anlam oluşturması için etkili bazı özelliklere sahip olması önem taşır. Burada kostümü etkili kılan, sembolik bir anlam taşımasına yardımcı olan unsur, giysinin filmin konusu olan döneme özgü olarak tasarımının yapılmasıdır. Anlatıda yer alan karakterin kostümünde döneme özgü algısını veren en önemli unsur öncelikle bunun temsil ettiği dönemin görsel özellikleri olmaktadır. Kostümün görsel yönünü oluşturan ise öncelikle giysi yapımında kullanılan dönemin toplum yaşantısında egemen olan dokumaların vurgulayıcı özellikleridir.

16. yy. Osmanlı dönemi saray yaşantısını konu alan dönem filmleri anlatısı oluşturulurken toplumda geçen olayları, toplumun kahramanlarını ve toplumun sosyo-kültürel yaşantı tarzını sembolize ederek yansıtma ya da bunlardan esinlenme kaygısı ile hareket edileceğinden ve filmin toplumdaki gerçeğe dair izler taşıması isteneceğinden anlatıda sembolik anlam taşıyan görsel göstergelerin döneme özgülügünün vurgulanması beklenmektedir. Dolayısıyla, filmde sembolik anlam taşıyıcısı olarak görev yapan kostümün döneme özgülüğünü ifade eden görsel araçlar olan dokumaların cinsi ve deseni önem taşıyacaktır. Bu çalışmada, öncelikle giysinin döneme özgülügünü ifade eden ipek lifli giysi dokumalarının sembolik anlam oluşturan özellikleri irdelenmekte ve daha sonra 16 . yy. Osmanlı dönem filmleri anlatısında ipekten üretilen dokumaların döneme özgü sembolik anlatım özelliğinden yararlanılması konusu ele alınmaktadır. Çalışmada eleştirel literatür değerlendirmesi ve görsel metin çözümlemesi yapılmıştır. 16. yy'dan günümüze kalan giysiler ve döneme özgü minyatürler arasından döneme özgülügü tam olarak verebilen örneklerden bir seçki yapılarak bu görsel metinler üzerinden çözümleme yapılmıştır. Çalışma ile 16. yy. Osmanlı dönem filmleri anlatısı oluşturulurken karakter tasarımı sürecinde ipekten üretilen dokumaların döneme özgü sembolik anlatım özelliklerinden yararlanılması hedeflenmektedir. 


\section{Yüzyıl Saray Dokumacılığında Öne Çıkan Hammadde Olarak İpek Lifinin Genel Özellikleri}

İpekli dokumaların Osmanlı döneminde saraya yönelik yapılan kumaşlar arasında değer kazanması özellikle hammaddesi olan ipek lifinin eşşiz özelliklere sahip olmasindan ileri gelmektedir.

Bireylerin gerek giyinme gerekse barınılan yerlerin düzenlenmesinde kullandıkları her türlü kumaş ve diğer materyaller, gerilebilme, bükülebilme ve birbiri üzerine yapışabilme yeteneği olan ve boyu enine göre çok uzun olan lif ya da lif kelimesinin çoğulu olarak isimlendirilen elyaf adı verilen hammaddeden yapılmaktadır (Başer, 1992, s. 1). Tekstil ise bu hammaddenin elde edilmesinden tüketicinin istediği özelliklere sahip bir kumaş ve materyal haline getirilinceye kadar geçirdiği aşamaları ve dolayısıyla süreci ifade etmektedir.

Bir tekstil ürünü olan ipekli kumaşların hammaddesi olarak ipek, ipek böceğinden (Şekil 1) üretildiği için bir doğal lif olup hayvansal lif türü içinde salgı kökenli lifler arasında yer almaktadır (Başer, 1992, s. 2).

Şekil 1. Kozası ile İpek Böceği.

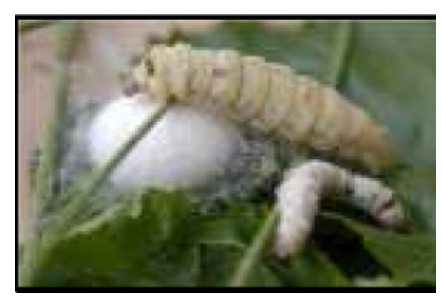

Kaynak: Atav ve Namirtı (2011, s. 112).

Yün ve benzeri diğer kıllar yanında önemli bir doğal yumurta akı (protein) lifi olan ipek Bombyx Mori türüne giren ipek böceğinin iki tip ipek salgı bezinden gelen salgının alt dudağın ucunda bulunan bir delikte birleşip tek tel haline çıkmasıyla meydana gelmektedir (Duran, vd., 2007, s. 182). İpek böceği bütün kozayı durmaksızın ördügünden kozadaki lif kesiksiz bir durumda bulunur ve genellikle bir kozadan kesiksiz olarak çekilebilen ipek teli miktarı 15-200 m. kadardır (Şekil 2).

Şekil 2. İpek Flamenti.

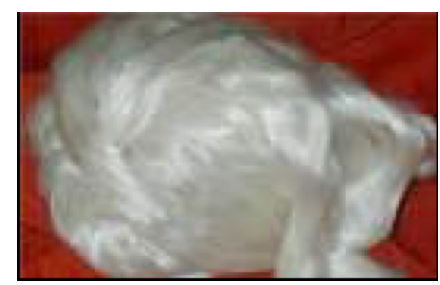

Kaynak: Atav ve Namirtı (2011, s. 112).

İpek, hayvansal lifler arasında en dayanıklı olan bir madde olup koparılmadan \%10 ya da \%25 oranında gerilebilir (Başer, 1992, s. 96). Ancak tasniflemede fazla kristalin 
olan yapısı ile elastik özelliğinden çok plastik özelliği ile anılmaktadır (Şekil 3). Ayrıca ipek lifi ışı̆̆ yansıtan prizma benzeri yapısı nedeniyle titrek parıltılar taşımaktadır (Ambrose ve Harris, 2007, s. 87).

Şekil 3. İpek Liflerinin Enine Kesitinin Görünümü.

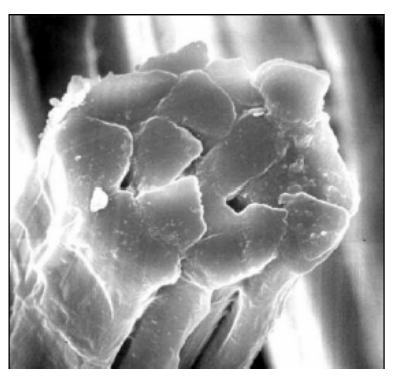

Kaynak: Duran, Özdemir ve Namllgöz (2007, s. 183).

Elyaftan lifin elde edilmesinden sonra kimyasal yollarla ve teknik yöntemlerle liflerin birbirine eklenmesi sonucu iplik meydana getirilir (İmer, 1987, s. 1). İplik, dokumayı meydana getiren en önemli unsurdur. İki iplik sisteminin (Şekil 4) belli kurallara göre dik açı yaparak kesişmesinden oluşan bir tekstil ürünü olan dokumayı meydana getiren boyuna ipliklere çözgü, yatay ipliklere de atkı denmektedir (İmer, 1987, s. 3).

Şekil 4. Atkı ve Çözgüden Oluşan Dokuma Deseni.

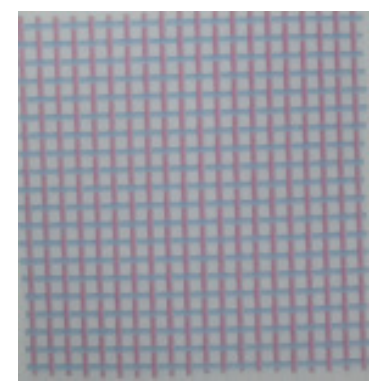

Kaynak: Ambrose ve Harris (2007, s. 88).

Özel bir tür ipek böceğinden elyafın üretim aşamalarının kendine özgü nadir özellikler taşıması ve üretimin zaman alması nedeniyle lifin elde edilmesinde yaşanılan güçlüklere rağmen ipek lifi dayanıklılığı, yapısında taşıdığı parıltı nedeniyle oluşturduğu görsel etki ve dokumada altın veya gümüş metal liflerle kolay karıştırılabilme özelliği nedeniyle saray için üretilen değerli kumaşların hammaddesi olarak tercih edilmiştir.

16. yy.da Bursa, kaliteli üretimleriyle Orta Doğu ipek sanayinin merkezlerinden biri olmuş, ipekli kumaşların Avrupa ülkeleri ve İran’a ihraç edilmesi Osmanlıların dokuma sanatında geldiği ileri düzeyi göstermiştir (İnalcık, 2008, s. 245-246). Saraya yönelik değerli kumaş üretimi yapan atölyeler içinde Bursa öne çıkmakta, ikinci s1rada da İstanbul atölyeleri yer almaktaydı. İstanbul atölyeleri seraser ve kemha gibi değerli ipekli dokuma üretiminde yoğunlaşmışsa da bu atölyelerde tüm aşamalar 
gerçekleşmemekte, ipek iplik ipliğin çekilip boyandığg Bursảdan getirtilmekteydi (Atasoy, vd., 2001, s. 156).

\section{Yüzyıl Osmanlı Dönem Filmleri Anlatısında İpekten Üretilen Dokumaların Döneme Özgü Sembolik Anlatım Özelliğinden Yararlanılması}

16. yy. ipek lifli dokumaların döneme özgü saray yaşantısındaki yerinin irdelenmesi dönem filmleri anlatısının oluşturulması sürecinde ipek lifli dokumaların anlatıdaki sembolik işlevini anlaşılır kılacaktır. 16. yy’a özgü dönemin saray giysileri, kalitesi ve gösterişi, aksesuarları, rengi, desen kompozisyonu ile bireylerin ait oldukları grupları ve grup kimliğini göstermede etkili adeta döneme özgü simgesel bir araç konumundadır. Saray dokumacılığında esas olarak saray halkı içinde önce padişahın daha sonra diğer hanedan üyelerinin giysi ihtiyacı karşılanmak istenmiştir. Özellikle, bu atölyelerde üretilen ipekli dokumaların sarayda ve devlet törenlerinde hiyerarşiyi belirlemede statü gösteren bir role sahip olduğu bilinmektedir (Bilgi, 2007, s. 12).

16. yy.da Osmanlı dokuma sanatı, değerli kumaşların üretimiyle ileri bir düzeye gelmiştir. Bu dönemin özelliği daha çok diba, kemha, seraser, atlas ve çatma gibi değerli kumaşların üretilmesi, bu kumaşların üzerinde lale, karanfil ve çintemani motiflerinin kullanılması ve kırmızı renk ve tonlarının hakimiyetinin olmasıdır (Beksaç, 2013, 33-37). İpekten üretilen değerli dokumalar, padişah ve saray mensuplarının giyimleri için özel olarak dokutulan üstün kumaşlar olduğundan bu tür kumaşlar saray kumaşları olarak adlandırılmıştır (Tez, 2009, s. 61). Padişah hanedanı ve saray mensupları halkın giyim biçiminden farklı bir bi-çimde özel dokutulmuş değerli kumaşlardan belli kurallara uyularak dikilen giysileri kullan-mışlardır. Biçim ve giyiniş tarzında kimi zaman benzerlik olsa bile saray giyimi kullanılan kumaş, malzeme ve süslemelerde ihtişamı sağlayan uygulamaların yapılması ile farklılığını üst düzeyde ortaya koymuştur. Bu durum 16. yy'da daha belirgin bir şekilde görülmektedir. Özellikle, değerli dokumalara eşlik eden süslemeler dokumaların ihtişamını daha da arttırmış, kumaş üzerindeki desen ve işlemeler ile değerli taşlardan oluşan aksesuarların (kemer, küpe, sorguç, yüzük, kılıç vs.) yapımı saray giyiminde süsleme sanatının karakteristik özelliğini oluşturmuştur. Saray hanedanı içinde kadınların (padişahın eşi, kızı, yakın akrabaları) giysi modellerinde genellikle bedene oturan, belden sonra etek ucuna kadar genişleyen, kollarda bileklere kadar dar olarak uzanan ve arka omuzlardan yere kadar inen elbise kumaşından yapılı pelerin görünümü veren klasik bir tarz görülmekte ve giysi çeşitli mücevher, altın / gümüş kemerler ve işlemelerle süslenmektedir (Atınay ve Yüceer, 1992, s. 56). Saray kadınının giysisinin biçim, renk, işleme ve süslemeleri saray ihtişamını temsil etmektedir. Saray erkek giyimi ise padişahın giyim tarzı olan kaftan ile sembolleşmiştir. Kaftanın biçim, renk, desen ve süsleme özellikleri ile giysi ile birlikte kullanılan değerli taşlardan oluşan altın ya da gümüş aksesuarlar padişahın konumunu ifade eden ihtişamı sağlayıcı unsurlardır. İçe giyilen kaftanlar daha düz kumaştan dar, uzun kollu, uzun etekli, önden bele kadar açık olarak üretilmiş olup dışa giyilen kaftanlar ise altın ve gümüş telle desenlendirilerek dokunmuş kumaşlardan dikilmişlerdir (Atınay ve Yüceer, 1992, s. 63). Genelde, saray içi günlük yaşamda önden açık, yakasız, önü kollu olan kaftanlar 
törenlerde kolların altından kaftan boyuna kadar uzanan uzun bir parçadan oluşan ihtişam sağlayan bir biçim almaktadırlar.

Osmanlı sarayına yönelik dokumacılıkta ipekli dokumalar iplik türüne bağlı olarak değer kazanmaktaydı, bunun yanı sıra renk, desen gibi unsurlar dokumanın değerini ar-tırmaktaydı ve ayrıca dokuma ipliğine altın ve gümüş telin katılması ipekli dokumayı daha da zenginleştirmekteydi (Bilgi, 2007, s. 11-12). Özellikle, kaftan yapımında kullanılan ipekli doku-mayı temsil eden değerli kumaşlar arasında en çok çatma, kemha, seraser öne çımakta olup kumaşlar arasında zerbaft adı verilen kumaş bazı motifleri altın telle dokunan bir brokar türü olması nedeniyle en değerli kumaş sayılyyordu. Diğer değerli bir kumaş ise seraser (Şekil 5) olup, bunun da çözgüsü ipek ve atkısı gümüş veya altın telden meydana gelmektedir.

Şekil 5. II. Selim’in Giydiği Kaftan ve Seraser Dokuma Örneği.

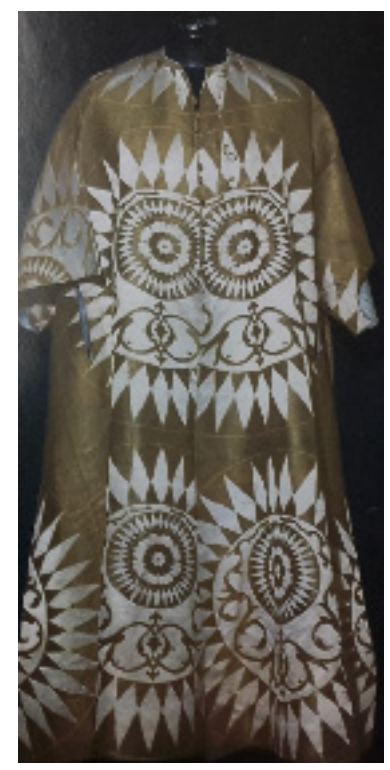

Kaynak: Altay (1979, s. 12).

(Kaftanın bulunduğu yer: Topkapı Sarayı Müzesi).

Osmanlı saray dokumacıl lğında klaptan ipek ipliğe sarılmış altın veya gümüş alaşım$l_{1}$ tel olup, altın sayısının artması kumaşın değerini yükseltmekteydi. Özellikle 17. yy. sonu ve 18. yy.dan itibaren giderek klaptandaki altın sayısının azalması klaptanın kumaşa kattığı değeri de azaltmış oldu.

16. yy.da klaptanın en çok kullanıldığı kumaşlar kemha ve çatmadır. Kemhanın (Şekil 6) çözgüsünü ve atkısını ipek, deseni oluşturan takviye atkılarını ise ipek ve gümüş ya da altın klaptan oluşturmaktaydı. Klaptan kumaşlar ipek ipliğe sarılmış altın veya gümüş alaşımlı tel olup, altın sayının artması kumaşın değerini yükseltmekteydi. Özellikle, kaftanlarda klaptandan oluşan desenler tercih edilmekteydi. 
Şekil 6. II. Beyazıt’’n Giydiği Kaftan ve Kemha Dokuma Örneği.

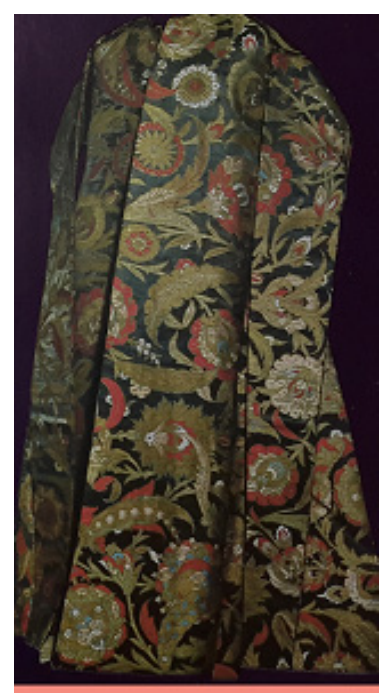

Kaynak: Altay (1979, s. 6).

(Kaftanın bulunduğu yer: Topkapı Sarayı Müzesi).

Bir dokunuş tekniği olarak kadifenin bir çeşidi sayılan çatmada (Şekil 7) ise genellikle zemin kadife ve desen gümüş klaptanla dokunmuş ya da tersi olarak zemin klaptanla dokunarak desenin kadife olması sağlanmıştır. Osmanlı döneminde ipekli kumaşların kullanım alanları arasında hilat, kaftan, seccade, perde, yastık yüzü, mobilya örtüsü yaygın olarak yer almaktadır.

Şekil 7. IV. Murad’ın Giydiği Kaftan ve Çatma Dokuma Örneği.

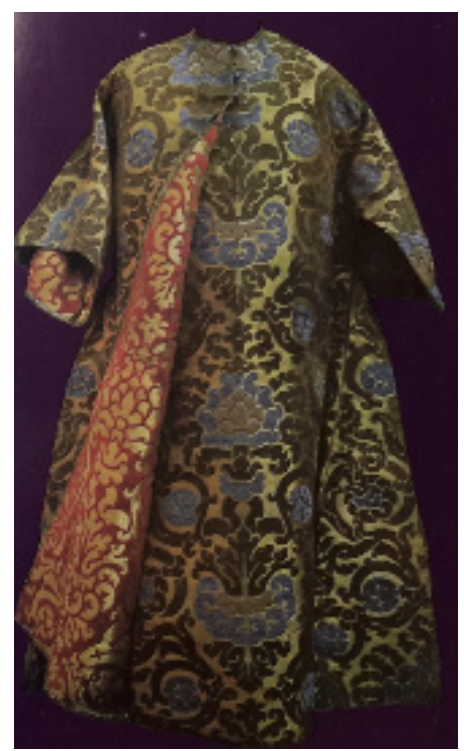

Kaynak: Altay (1979, s. 24).

(Kaftanın bulunduğu yer: Topkapı Sarayı Müzesi). 
Seyyid Lokman’’n yazdığı ve Nakkaş Osman tarafından tasvirlenen Kıyafetü’l İnsaniyye fi Şema’ili'l Osmaniyye adlı elyazmasındaki minyatürlerden padişahların giyim özellikleri hakkında bilgi edinilmektedir. Sultan Beyazıt'ın tasvirinin yapıldığ1 bir minyatürde (Şekil 8) sultanın çatma denilen kadife kumaşa benzeyen değerli bir ipekli dokumadan içi kızıl kahve tonda kürk astarlı kaftan giydiği görülmektedir (Lokman, 1601, 194-195).

Şekil 8. Nakkaş Osman Tarafından Tasvirlenen Değerli Dokumadan Oluşan Kaftan Giymiş Sultan Beyazıt Portresi.

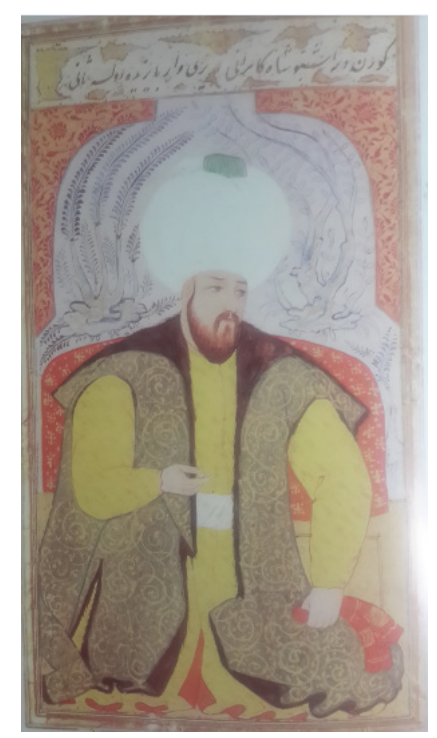

Kaynak: Seyyid Lokman [1601], yayına haz., Duran (1999, s. 194).

(Minyatürün bulunduğu yer: Millet Kütüphanesi Kiyafetü'l İnsaniyye fi Şema’ili'l Osmaniyye Ali Emiri Efendi Nüshas1 1216 Millet Ktb.AG 41b).

Nakkaş Osman tarafından tasvirlenen Kıyafetü’l İnsaniyye fi Şema'ili'l Osmaniyye adlı elyazmasındaki Kanuni Sultan Süleyman Portresinde (Şekil 9) de padişahın giyim özellikleri hakkında bilgi edinilmekte ve sultanın hatayi motiflerinden oluşan değerli bir ipekli dokumadan yapılmış içi beyaz renkte kürk astarlı kaftan giydiği görülmektedir (Seyyid Lokman, [1601], s. 232-233). 
Şekil 9. Nakkaş Osman Tarafından Tasvirlenen Değerli Dokumadan Oluşan Kaftan Giymiş Kanuni Sultan Süleyman Portresi.

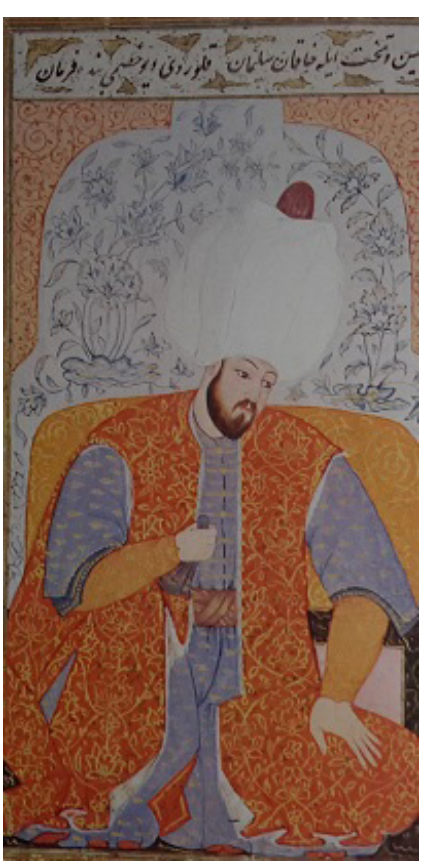

Kaynak: Seyyid Lokman [1601], yayına haz., Duran (1999, s. 232).

(Minyatürün bulunduğu yer: Millet Kütüphanesi Kiyafetü'l İnsaniyye fi Şema’ili'l Osmaniyye Ali Emiri Efendi Nüshası 1216 Millet Ktb.AG 51a).

Portresi yapılan çocuk padişah olan 14 yaşındaki I. Ahmed'in tasvir edildiği bir minyatürde (Şekil 10), genç sultan, mavi zemin üzerine sarı klaptanla dolaşma desenli bir ipekten oluşan dış kaftan giymiş olarak tahtta otururken betimlenmiştir (Tezcan, 2006, 54). Resimdeki kumaş üzerindeki sarı dokumalar klaptanın altınla oluşturulduğunu işaret etmektedir. 
Şekil 10. Çocuk Padişah Tahtta Oturan "Civan Sultan" Denilen I. Ahmed’in Portresi.

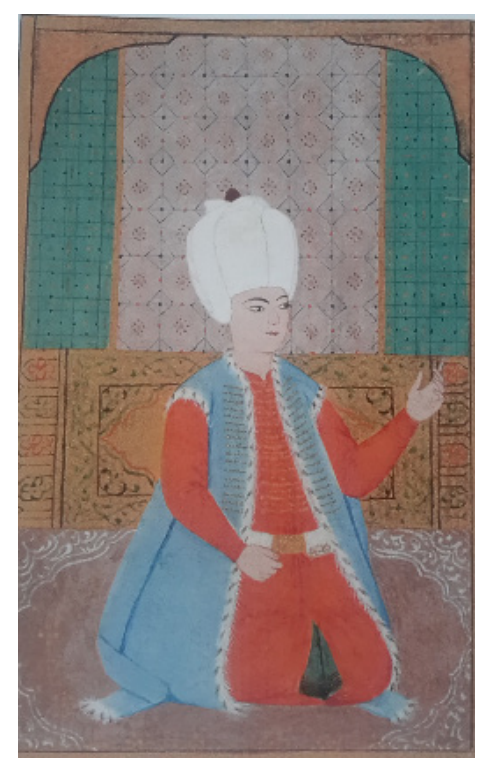

Kaynak: Tezcan (2006. s. 54).

(Minyatürün bulunduğu yer: İstanbul Üniversitesi Kütüphanesi IÜK T9366 26a).

İntizami’nin yazdığı ve Nakkaş Osman tarafından tasvirlediği Sultan III. Murat’ın şehzadesinin sünnet düğünü şenliklerini betimleyen Surname-i Hümayun adlı elyazmasındaki bir minyatürde de (Şekil 11) divan üyelerine ve diğer saray mensuplarına giydirilen Hilatların altın klaptanla desenlenmiş değerli ipekli kumaşlardan yapıldığı görülmektedir (İnalcık, 2008, s. 247).

Şekil 11. Nakkaş Osman tarafından tasvirlenen Surname-i Hümayun'dan bir Sahne.

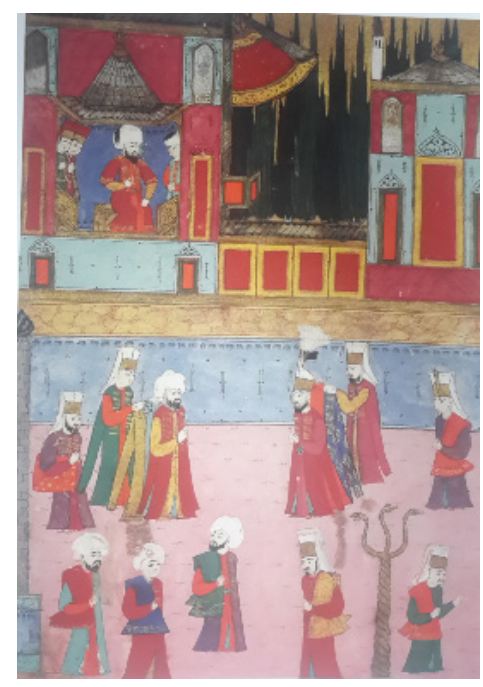

Kaynak: İnalcık (2008, s. 247).

(Minyatürün bulunduğu yer: Topkapı Sarayı Müzesi Kütüphanesi Surname-i Hümayun TMSK H1344 426a). 
Nakkaş Ahmet Nakşi tarafından at üstünde Genç Osmanın betimlendiği bir minyatürde (Şekil 12) Genç Osman’ın altın klaptanla oluşturulmuş desene sahip bir dış kaftan giydiği görülmektedir (Tezcan, 2006, s. 55).

Şekil 12. Nakkaş Ahmet Nakşi tarafından tasvirlenen At Üstünde Oturan "Genç Osman" denilen II. Osman’n Portresi.

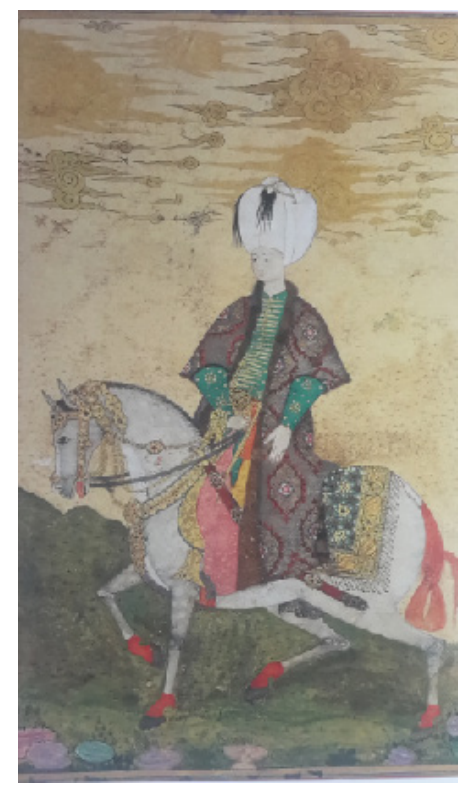

Kaynak: Tezcan (2006, s. 55).

(Minyatürün bulunduğu yer: Topkapı Sarayı Müzesi Kütüphanesi TMSK H2169 13a).

\section{Sonuç}

Çalışmada, 16. yy. Osmanlı dönemi toplum yaşantısını konu alan dönem filmi anlatısında ipek lifli giysi dokumalarının bir simgesel anlatım aracı olarak özellikleri açıklanmıştır. 16. yy. ipek lifli dokumaların döneme özgü özelliklerinin irdelenmesi, dönem filmleri anlatısının oluşturulması sürecinde ipek lifli dokumaların anlatıdaki sembolik işlevinin anlaşılmasını ve böylece anlatıda özellikle karakter ve karakterin içinde bulunduğu mekan tasarımında dokumaların sembolik anlatım özelliğinden yararlanılmasını sağlayacaktır.

16. yy. Osmanlı dönemi saray yaşantısında kullanılan ipekli giysi dokumaları padişah ve sarayın ihtişamını vurgulayan sembolik bir özelliğe sahiptir. 16. yy. Osmanlı sanatı her alanda renk, desen-bezeme, kompozisyon, hammadde ve teknikleriyle ileri düzey örneklerin verildiği bir dönem olmuş ve özellikle saray için üretilen dokuma / kumaşlar da bu devirde değer kazanıp öne çıkmıştır. Saray dokumacılı̆̆ı olarak isimlendirilebilen bu alanda üretilen dokumaların, padişah ve sarayın sosyal hiyerarşide en üst konumda yer alışını gösteren simgesel özelliklere sahip olmasına çalışılmıştır. Bu simgesel özellikler padişah ve sarayın ihtişamını artırmayı sağlayan ipek lifinden oluşturulan değerli dokumalar ve bu dokumalara eşlik eden süslemelerdir. Gerek do- 
kumaların desen ve işlemelerinde gerekse giysi ile birlikte kullanılan aksesuarlarda metal liflerinden altın veya gümüşün yer alması tercih edilmiştir.

16. yy. Osmanlı saray yaşantısını konu alan dönem filmleri anlatısında saray yaşantısinda önemli rol oynayan öncelikle padişah ve sonra diğer şehzade, hanedan üyeleri, saraydaki üst düzey görevliler gibi saray mensuplarını temsil eden karakterlerin kostümlerinin tasarımında kullanılacak dokumaların, dönemin sosyal hiyerarşisindeki üst düzeydeki konumlarını sembolize edecek şekilde ipekten ya da ipek görünümüne sahip değerli kumaşlardan yapılmasının sağlanması gerekir. Ayrıca, anlatıda padişah, şehzade ve üst düzey görevlileri temsil eden karakterlerin kostümlerinin dokumalarında konumlarının özelliklerini vurgulayabilmek için altın ve gümüş klaptandan ya da bu görünümü veren metallerden desenlerin oluşturulması karakterlere yönelik gerçeklik algısının oluşmasında önemli rol oynayacaktır. Burada karakterin özelliğinin tam olarak vurgulanabilmesi için kostümlere eşlik eden aksesuarların (mendil, yüzük, sorguç, küpe vs.) ve iç mekan dekor nesnelerinin (divan, perde, örtü, yastık, minder halı vs.) dönemin dokuma ve bezeme anlayışına uygun olarak oluşturulması gerekli olacaktır. Giysi aksesuarlarındaki ve karakteri çevreleyen mekandaki dokumalarda ipek lifli kumaşların kullanımı karakter kostümlerinin dokuma özelliklerinin değerini döneme uygun bir şekilde öne çıkarıp arttıracaktır.

Dönem filmleri için karakter tasarımının oluşturulmasında karakter ve karakteri destekleyici işleve sahip olan mekanın temsil ettikleri dönemin sembolik anlam taşıyan unsurlarına sahip olması önem taşımaktadır. 16. yy. Osmanlı dönemini sembolize eden unsurlar arasında öncelikle dokumalar öne çıkmaktadır. Bundan dolayı bu unsurların karakter tasarımı sürecine dahil edilmesi anlatıda gerçeklik algısının oluşmasına olanak sağlayacaktır.

\section{Kaynakça}

Altay, Fikret (1979). Kaftanlar. İstanbul: Yapı ve Kredi Bankası Kültür ve Sanat Hizmetleri.

Altınay, Hüsniye ve Halime Yüceer (1992). Moda ve Tarihi. Ankara: Kadığlu Matbaasi.

Ambrose, Gavin ve Paul Harris (2007). Görsel Moda Tasarımı Sözlüğ̈̈. İstanbul: Literatür.

Atasoy, Hülya, Walter B. Denny, Louise W. Mackie ve Hülya Tezcan (1991). Ípek: Osmanlı Dokuma Sanatı. İstanbul: TEB.

Atav, Rıza ve Osman Namırtı (2011). “İpek Liflerinin Dünü ve Bugünü”, Mühendislik Bilimleri ve Tasarım Dergisi, 1/3.

Başer, İnci (1992). Elyaf Bilgisi. Marmara Üniversitesi Teknik Eğitim Fakültesi, İstanbul: Marmara Üniversitesi Yayınları.

Beksaç, Şule (2013). Osmanlı Dokuma Sanatından Esintiler. Edirne: Ceren Yayınları. Bilgi, Hülya (2007). Osmanlı İpek Dokumaları-Çatma ve Kemha. İstanbul: Sadberk Hanım Müzesi.

Duran, Kerim, Duygu Özdemir ve Eylen Sema Namlıgöz (2007). “İpek Liflerindeki 
Serisinin Enzimatik Olarak Uzaklaştırılması". Tekstil ve Konfeksiyon Dergisi, 3. İmer, Zahide (1987). Dokuma Tekniği. Ankara: Cem Web Ofset.

İnalcık, Halil (2008). Türkiye Tekstil Tarihi Üzerine Araştırmalar. İstanbul: Türkiye İş Bankası Yayınları.

Seyyid Lokman [1601]. Kıyafetü'l İnsaniyye fi Şema’ili'l Osmaniyye. Yay. Haz. Tülay Duran (1999). İstanbul: Tarihi Araştırmalar Vakfı İstanbul Geliştirme Merkezi. Tez, Zeki (2008). Tekstil ve Giyim Kumaşın Kültürel Tarihi. İstanbul: Doruk Yayınları. Tezcan, Hülya (2006). Osmanlı Sarayının Çocukları-Şehzadeler ve Hanım Sultanların Yaşamları, Giysileri. İstanbul: Aygaz. 
İNSAN\&İNSAN, Sayı/Issue 4, Bahar/Spring 2015

ISSN: 2148-7537, www.insanveinsan.org

\title{
The Features of Silk Fiber Clothing Weavings Relating to Period Being a Symbolic Meaning Producer for the 16th Century Ottoman Period Film Narrative
}

\author{
INCI YAKUT
}

\begin{abstract}
In this study, it has been examined which features have silk fiber clothing weaving as a symbolic narration means in the 16th Ottoman period film narrative. Examining symbolic features relating period that silk fiber weaving have will provide silk fiber weaving to be understood symbolic meaning creating level at character design at the period film narrative making proccess. It has been made critical literature assessment and visual text analysis. Silk fiber weaving used in the Ottoman period court life has a symbolic feature focusing on magnificence of sultan and court. Weavings used in costume designs of characters representing sultan and the other court members in the real court life for Ottoman period film narrative must have silk fiber or silk appearance valuable fabrics symbolizing social status of period. These create reality perception for character, space and events. Additionally, to be used silk fiber fabrics in clothing accessories and space weavings surrounding character will put forward value of weavings features of character costumes.
\end{abstract}

Keywords: Otttoman period film, Narrative, Symbolic meaning, Silk fiber clothing weaving, Character design, Costume. 